\title{
Islamic charity based micro-finance: lessons from Indonesia
}

\author{
Aimatul Yumna \\ Universitas Negeri Padang, Padang, Indonesia, $\bowtie$ Aimatulyumna@gmail.com
}

\begin{abstract}
This paper provides the basic concept and implementation of the use of Islamic charity for microfinance initiatives in Indonesia. Using case study approach, this paper will evaluate the sustainability and the outreach of three institutions, including Baitul Qiradh Baznas, Baitul Maal Mualamat Indonesia, Baitul Maal Beringharjo. Data was collected using a survey of 270 questionnaires from clients and non-clients and conducted nine interviewed with the four fieldworkers and five senior managers. Data will be analyzed using both quantitative and qualitative approach.The findings indicated that each institution demonstrated its capability to enhance its funding collections. The increasing amounts of funds collected by institutions can be correlated with the success of the institutions in adopting innovative fund raising strategies and promoting empowerment programs. However, the problems of limited community supports, high operational cost and low repayment rate are also significant affecting institutional sustainability. The study's findings also point out a lack of participation by the poorer in ICBM programs. Some factors that can contribute to the lack participation are institutional clients selection policy, self exclusion and selection mechanism. This research will add to literature calls for increased empirical evidence of the benefits of utilizing Islamic charity in microfinance.This study will also contribute to the further development of micro-finance by providing an alternative micro-finance model that may work in more efficient and effective ways for the poorest.
\end{abstract}

Keywords : Islamic charity, zakat, micro-finance, institutional sustainability, outreach

\section{Introduction}

This study examines the nexus between Islamic charity and micro-finance. It will consider the proposition that micro-finance has a greater chance of being sustainable and more inclusive of the poorest members of society if Islamic charity is used as a significant source of funding. This study will test this proposition through the use of case studies of three Islamic charity based micro-finance (ICBM) institutions in Indonesia.

Islamic charity is significant in Indonesia, being approximately $3.4 \%$ of the national GDP in 2010 (Firdaus et al., 2012). It is estimated that approximately one-third of funds collected by Islamic charity institution during the period of 2004 to 2014 is distributed through mechanisms that enable the poor to gain long term benefits from the charity such as improved access to education and training and to economic empowerment programs (IRTI, 2014).

Despite the availability of Islamic charity, poverty and financial exclusion is still widespread in Indonesia. Although the poverty rate has been steadily decreasing from $23.4 \%$ in 1999 to $12.5 \%$ in 2011 , more than $40 \%$ of the country's population is categorized as financially vulnerable and exists on the edge of poverty (The World Bank, 2012b). Of this financially vulnerable sector, less than half have access to financial services (Bank Indonesia, 2013). Existing providers of microfinance only target a specific segment of the population and as such may fail to provide financial services to poor clients (Nugroho, 2010). It is documented that $99 \%$ of micro entrepreneurs have no access to financial services (MKUKM, 2012). Islamic charity has been suggested as a potential source of funds to increase financial inclusion and to provide financial access to the micro entrepreneurs who currently have limited access to financial services (Mohieldien et al., 2011). To what extent and how Islamic charity can be utilized in microfinance will be explored theoretically and empirically in this study.

The research reported in this study is located at the intersection of two areas of study: Islamic charity and microfinance. It is expected that the research findings presented in the study will 
contribute to knowledge and understanding of these areas in two key respects. Firstly, the research findings will add to literature calls for increased empirical evidence of the benefits of utilizing Islamic charity in microfinance. The major studies, for example Obaidullah (2008), Hassan (2010), Kaleem and Ahmed (2009) provide theoretical discussions and develop various models to integrate Islamic charity and microfinance, whether these study findings are supported or not has however, yet to be explored. Empirical research studies are therefore needed to advance existing ICBM theory. In addition, issues around sharia compliance and effectiveness of Islamic charity as religious instruments in lending provision remain debatable in the literature (see Sarif and Kamri, 2009; Wan Ahmad and Mohamad, 2012). This study will contribute to the Islamic microfinance literature by showing empirical evidence of the sustainability and outreach of ICBM institutions in Indonesia.

Secondly, it is expected that the study will contribute to the further development of microfinance by providing an alternative microfinance model that may work in more efficient and effective ways for the poorest as mentioned by Ledgerwood (2013) that microfinance has become more broadly inclusive by providing equitable financial access to all segments of the poor.

\section{Literature reviews}

\section{Islamic charity : zakat, shadaqa and waqf}

In Indonesia, the collection and distribution of Islamic charity can be done through various channels. Traditionally, zakat is distributed directly from the rich Muslims to the prospective recipients. It is more personal and largely for consumption purposes. Although the direct distribution still continues, there are significant change in the way people pay zakat and other Islamic charity since the emergence of zakat organizations in 1960s. There are three types of Islamic charity that are commonly paid by Muslim, including zakat, shadaqa and waqf.

Zakat refers to the transfer of wealth from the wealthier 'haves' to the poor in order to facilitate the redistribution of income and wealth in the society (Kahf, 1989). In Sharia, the word zakat refers to the determined share of wealth prescribed by God to be distributed among deserving categories. Islam considers that all things belong to God; therefore possession has to be purified.Zakat is one of the most regulated types of charity mentioned in the Qur'an. Islamic laws refers to several inherent characteristics of zakat in relation to its recipients and its distribution mechanisms. Firstly, Islam provides a clear definition of who can be a beneficiary of zakat. As noted in the Qur'an (9.60), zakat can only be given to eight categories of people: the poor, the needy, workersin zakat administration, newly converted Muslims, liberated slaves, those who are in debt, those who work for the sake of God, and wayfarers. Among those categories, the poor and the needy are mentioned earlier in the verse of 9:60 indicating that the primary function of zakat is to provide basic resources to meet the basic survival needs of the poor and the needy. According to Kahf (2006) extending relief to the poor and needy is the top priority of zakat disbursement. Specifically, zakat may be distributed to those who have little or no income, orphans, the sick, the disabled and the homeless (Obaidullah 2008).

Zakat must be paid directly to the eight categories mentioned above and disbursed within one financial year (Hassan, 2010). According to Qardhawi (2009), any investment, or capitalization of zakat funding is prohibited. Many scholars confirm that zakat must be paid directly when accumulated assets reach nisab(Wan Ahmad and Mohamad, 2012). Consequently, zakat becomes a one off means of assistance that is most often used to finance immediate and pressing needs of the recipients. This condition limits the role zakat can play in the provision of funding for longer-term poverty alleviation interventions.

Unlike zakat, shadaqa is the most flexible type of Islamic charity. The term shadaqa comes from the root word sidq which implies giving away goods and funds for the sake of God as an expression of faithfulness and in realization of the belief in resurrection and afterlife (Qardhawi, 2009). In modern times, shaqada is more usually understood as charitable donations for those who are needy in the sake of God. Obaidullah (2008) notes that shadaqa may include various forms of charity, such as donations, gifts, and charitable spending. Related verses in the Qur'an mostly discuss the benefits and advantages of shadaqa for the donors (QS 9:99; 34:39; 2:274), while some of verses (QS 2: 261-264) 
emphasize the importance of being respectful towards the recipients. The major driver in the distribution of shadaqa funds is the concept of birr, orrighteousness. As such, shadaqa practices are more flexible and may add greater benefits for society (IRTI, 2014).

In addition, waqf can be found as other types of Islamic charity that has importantn role in development. In sharia, waqf means the holding of certain physical assets and preserving these for the long term benefit of society. Ahmed (2004) notes that waqf is a form of on-going shadaqa. The difference between waqf and ordinary shadaqa is that ordinary shadaqa is used for direct consumption purposes; while ongoing shadaqa is used to maintain the value of donated assets while the outcomes of a waqf-funded project are expected to achieve long term individual and social benefits. Islam encourages its followers to give on-going shadaqa that can be used to continuously generate benefits for the society.

Evidence shows that in early Islamic society waqf made a significant contribution to the economy. For example, in several countries such as the Republic of Turkey, Egypt, Iran, and Tunisia, a significant proportion of cultivated land constituted part of the waqf funded asset base (Kuran, 2001). In these countries, waqf has played important roles in various sectors including religion, education, and health. Waqf can offer greater flexibility in its utilization and has the potential to be utilized as a source of funding to alleviate poverty alleviation. However, there are many challenges in utilizing cash waqf for poverty alleviation as documented by some studies. For example, Affandi and Nufus (2010) argue that the collection and allocation of cash waqf in Indonesia is still both ineffective in achieving anticipated outcomes and underutilized as a microfinance funding resource. Other researchers have identified problems with the use of waqf funding such as a lack of trust in existing government institutions' capabilities in relation to managing cash waqf funds and controlling their investment activities, a serious lack of transparency and accountability, and a lack of managerial professionalism (Masyita et al., 2005, Ihsan and Ibrahim, 2011).

\section{Islamic charity based microfinance}

There are two models of the integration of Islamic charity in microfinance: the pure charity model and the integrated model. The pure charity microfinance model uses a combination of Islamic charity funding sources to provide both social and commercial services. Zakat, as a compulsory Islamic levy, is mainly used to provide resources to enable the poor to meet their basic needs and for skills training programs, while voluntary types of Islamic charity -shadaqa and waqf can be used to provide funds for commercial services (Kaleem and Ahmed, 2009, Obaidullah, 2008). Zakat is specifically designed to fund the provision of resources to enhance client wellbeing and to expand the capabilities of the poorest. Zakat can be used to fund social services in three key areas: providing resources to enable clients to meet their basic needs, providing training and skills enhancement programs and providing capital grant/interest free loans for the initial capital.

The second model presents an integrated model of Islamic charity and Islamic microfinance institutions as discussed by Ahmed (2007), Obaidullah (2008) and Hassan (2010). The integrated model uses a combination of both commercial funds and Islamic charity. Commercial funds are used to finance the commercial services, while Islamic charity is used to finance social services. Islamic charity plays an important role in addressing the adverse circumstances the poorest find themselves in prior to participating in microfinance programs. Similar to microfinance institutions, the integrated model offers commercial services such as micro saving and micro credit facilities, micro-insurance, and micro-leasing using Islamic financial schemes of transactions. However, this integrated model could face many challenges in its implementation due to conflicting organizational culture, policy and regulatory framework between social and commercial functions within the integrated model itself (IRTI, 2014).

The complimentary and collaborative use of Islamic charity and microfinance has two main advantages: it increases financial inclusion and it enhances institutional sustainability. Taking the first advantage, the poorest are excluded from the microfinance services because they are still struggling to meet their basic survival needs. Scholars argue that Islamic microfinance can utilize zakat funds to 
provide for these basic needs and for the funding of training to increase the skills of the poorest of the poor (Ahmed, 2007). Furthermore, Obaidullah (2008) believes that Islamic charity has a role to play in assisting the economically inactive poor to become economically active and to facilitate their greater involvement as participants in microfinance. Islamic charity can be distributed in the form of noninterest loans that can be accessed by all segments of the poor and as such, in this way could increase financial inclusion in Muslim countries.

In relation to the second advantage, the use of Islamic charity in microfinance could also enhance the financial sustainability of Islamic microfinance institutions (MFIs). Mohieldien et al. (2011) argue that the use of charity as a source of funds will reduce the financial costs of microfinance institutions and increase operational efficiencies. It has been argued that one of the main causes of high rates of non-performing loans in microfinance institutions is due to clients' use of funds for direct consumption purposes rather than for productive income producing purposes. By using charity for taking care of clients' basic needs, Islamic microfinance can reduce the possibility of asymmetric information and moral hazard problems and as an outcome, may lead to better loan repayment rates and increased financial sustainability (Ismail and Possumah, 2013).

Overall the literature review highlighted significant benefits of using Islamic charity as a microfinance source of funding. However, there is little empirical research that explores these benefits. This study, therefore, will evaluate the ICBM institutional sustainability and outreach to provide empirical contributions to the Islamic microfinance field of study.

\section{Methods}

This study will employ case study methodology as the overall research approach. The case study approach enables the researcher to investigate the results of the decision to use Islamic charity as microfinance program's source of funding: whether Islamic charity is able to enhance institutional sustainability, or able to increase participation of the poorest in the program.

This study collected both primary and secondary data. The primary data was collected using semi structured interviews, survey questionnaires, and direct observations. Secondary data was collected through the content analysis of government publications, institutional reports and a microfinance consultant's publications.

Three institutions including Baitul Qiradh Baznas (BQB), Baitul Maal Muamalat Indonesia (BMMI) and BMT Beringharjo were selected as case study institutions. The study collected a total of 270 questionnaires from ICBM clients and non-clients and conducted nine interviewed with the four fieldworkers and five senior managers. Data will be analyzed using both quantitative and qualitative approach.

\section{Result and Discussion}

\section{The program design}

The collection of Islamic charity in Indonesia is managed by three categories of institutions: Badan Amil Zakat (BAZ) as a state owned zakat institution, Lembaga Amil Zakat (LAZ) as a private zakat institution, and Unit Pengumpul Zakat (UPZ) as the appointed agents for zakat collection. Currently, BAZ is established in 33 provinces, 277 district level institutions and in 3160 sub-districts. In addition, there are approximately 200 LAZ institutions (IZDR, 2010). In this case study, three institutions were selected to represent three categories of Islamic charity institutions: Baitul Qiradh Baznas (BQB) is a state owned zakat institution (BAZ) and Baitul Maal Muamalat Indonesia (BMMI) is a private zakat institutions (LAZ) and Baitul Maal Beringharjo (BMB) is an apponted agents for collecting zakat (UPZ). The microfinance program of each institutions is described below.

\section{Baitul maal Muamalat Indonesia (BMMI)}

BMMI, a representative of private zakat organizations, was established in 2000 as a social subsidiary of Bank Muamamal Indonesia that collects Islamic charity from Bank Muamalat's clients 
and distributes this charity for social purposes. BMMI operations are directly linked to branches of Bank Muamalat Indonesia in most provinces in Indonesia.

BMMI's main program centers on economic empowerment. Seventy percent of its funds are distributed for this purpose through microfinance programs. The programs include three initiatives: Komunitas Usaha Mikro Muamalat Berbasis Masjid (KUMMM), Koperasi Jasa Keuangan Syariah KUMMM (KJKS KUMMM), and Lembaga Keuangan Mikro Syariah (LKMS). These programs have been designed to run as continuous programs that aim to include the poor within the microfinance system by offering different products and services with different periods of interventions and targeting different client profiles.

BMMI microfinance programs, Komunitas Usaha Mikro Muamalat Berbasis Masjid (Micro entrepreneur community based on mosques/KUMMM), were initially developed in 2007. This KUMMM program is especially designed for micro entrepreneurs who actively participate in the local mosque. The key objectives of the program are firstly, to work toward economic empowerment of the poor and secondly to support religious education for society. This second objective is translated into the institution's mission statement as an intention to develop an individual character with strong religious beliefs, a determined commitment to grow, and with the capacity to empathize with others. This mission statement emphasizes the need to enhance participants' wellbeing and to support growth in their understanding of Islam.

BMMI KUMMM microfinance program activities, including client selection, mentoring and loan repayment arrangements are conducted in the mosques. By centralizing these activities in the mosque, the institution believes that it will be able to choose clients who are motivated towards and committed to the adoption of positive attitudes and values. These client characteristics may go some way to reduce asymmetric information and moral hazard problems (S Kalifatullah, 2012). This approach is understood to replicate features of the Al Akhuwat microfinance model in Pakistan.

KUMMM program offers a continuation program by establishing financial cooperatives for the community surrounding the mosques, named as Koperasi Jasa Keuangan Syariah (KJKS). This cooperative is registered with the Ministry Cooperative and is regulated as a semi-formal organization under cooperative law. The members of the cooperative are successful graduates of the KUMMM program. KUMMM management expects that successful graduates will manage their own cooperatives and begin to participate in commercial microfinance. The role of BMMI is to provide the initial capital and to cover initial operating costs, as well as provide training in $\mathrm{KJKS}^{\prime}$ standard operating procedures. Similar to other financial cooperatives, KJKS also offers various commercial Islamic transaction schemes to cover its operational costs. At this point, continuation program of KUMMM is no longer offering an interest free financing under qard hassan scheme.

\section{Baitul Qirad Baznas}

The second institutional case study presented in this study is BAZNAS. BAZNAS is the nationalstate owned zakat institution established in 2000 to manage the collection and distribution of Islamic charity in Indonesia. BAZNAS has a central role in the Islamic voluntary and charity sector in Indonesia as all this sector's activities, including charity collection and distribution, have to be reported to BAZNAS.

The BAZNAS program covers several areas in education, economy, health and natural disaster assistance. The BAZNAS economic programs are aimed at empowering zakat recipients to increase their productivity and income levels by using Islamic charity alone. One of the services BAZNAS provides is the provision of interest-free loans under the Baitul Qiradh Baznas (BQB). The BQB program will be the focus of the analysis and discussion of this case study as it represents an exemplar institution in relation to its Islamic charity funded microfinance programs.

The BQB microfinance programwas developed in February 2010. At the beginning, BQB's operations were profit oriented. Using commercial Islamic transaction schemes, BQM distributed its funds from infaq and shadaqa in the form of microloans for the poor. At that time, BQB was experiencing problems as they were attempting to achieve profitability under the constraint of poor 
clients who were often facing difficulties with their loan repayments. As a result, the number of nonperforming loans in BQB was very high. Latterly, BAZNAS management considered re-orienting BQB's mission from being a commercial microfinance institution towards a voluntary microfinance institution.

The re-orientation of BQB began in early 2011. Since then, BQB has taken a position as amentoring institution that provides Qard hassan loans and personal mentoring services (BQB-1, 2011). This program aims to assist zakat recipients raise their income levels, strengthen their work ethos, and reduce their dependency on informal money lenders.

\section{Baitul Maal Beringharjo}

Baitul Maal Beringharjo is a social unit of Islamic financial cooperatives named BMT Beringharjo located in Yogjakarta. BMT itself is a unique type of Islamic microfinance institution that includes two units: Baitul Tamwil as commercial function and Baitul Maal as social unit. Similar to the other commercial microfinance institutions, BMT Beringharjo offers savings and financing products using Islamic schemes of transaction.

BMT Beringharjo is one of the examples of BMTs that maintains the existence of Baitul maal as the social unit to serve the community. The role of Baitul maal is to collect Islamic charity from BMT Beringharjo clients and stakeholders of BMT Beringharjo, which will be distributed for empowerment programs for the poor. In BMT Beringharjo, baitul maal (BMB) as a social function, constitutes a division under direct supervision of the BMT director. BMB represents one of the models of ICBM in Indonesia. Unlike the other voluntary microfinance models presented in the previous chapter, this voluntary microfinance institution works within BMT as the commercial arm of a cooperative type of microfinance institution.

From its initiation to the present, products and services offered by BMB have evolved significantly in response to market driven demands to offer improved empowerment programs. From 1994 to 2002, BMB offered only qard hassan loans. This type of loan is provided on an individual basis and as such, without any additional group mentoring. Mass mentoring was given to provide religious education and to build connections between clients and the institutions. BMB management argued that mass mentoring on its own was not capable of empowering the poor, thus the institution developed the idea of group mentoring in 2002. Individual qard hassan loan schemes and mass mentoring were terminated and replaced by a package of services that focus on three areas: economic empowerment, client development, and charity programs.

The BMB's economic empowerment programs target the poorest level of the poor and have an important role to play in both preparing members of this client group to become more entrepreneurial in their outlook and in expanding opportunities for their financial inclusion. The BMB programs are conducted in three phases. In the first phase, Sahabat Ikhtiyar Mandiri (SIM) is offered for the poorest level of the poor. In the second, Sahabat Mudharabah Kebajikan (SMK) targets graduates of SIM programs, and in the third phase, Mentas Unggul, an advanced empowerment program, selects the best SMK graduates to be coached as entrepreneurs. Each program in each phase targets different clients and is designed to achieve different objectives. After having participated in a series of economic empowerment programs, the graduates of these advanced empowerment programs are expected to be clients of Baitul tamwil.

In addition to the provision of services to the poorest and the poor, Baitul maal also offers some development programs for Baitul tamwil clients who are mainly new entrepreneurs with a small asset base. One of these programs, BINAR, offers direct assistance in book keeping and professional skills enhancement training. This free service of BMT assists new entrepreneurs to grow and reach their potential. BINAR graduates developed Binar Family (BIFA) as an ambassadorial program that represents and is run by successful participants. Operating independently, this program's periodic meetings help BMT Beringharjo to reach more customers. BINAR graduates also volunteer to become casual trainers for other empowerment programs. Depicted in the Figure 1, these particular programs 
can be seen as a cycle of intervention that complements each other. This model shows how in concert, BMT's social functions can be advantageous to commercial functions, and vice versa.

Provider Product and Services

Clients

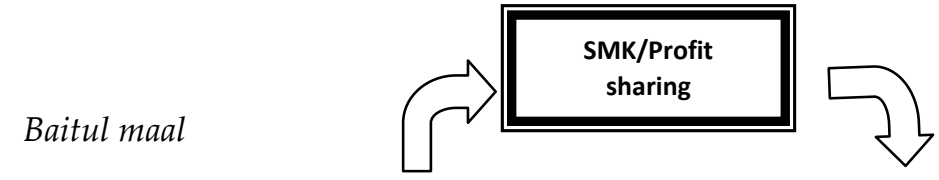

The poor and extremely poor

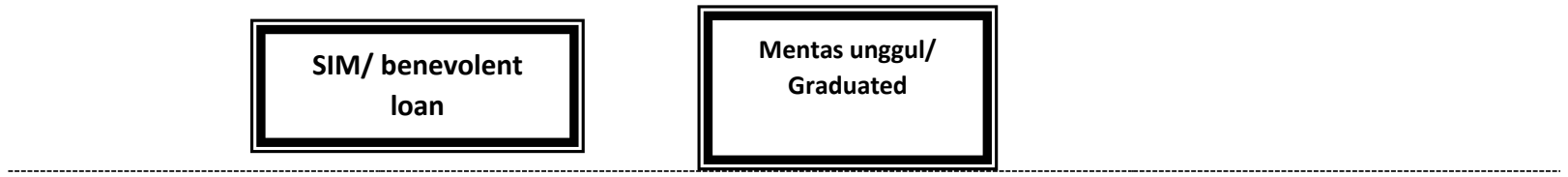

Baitul tamwil

BINAR/

Professional

Source: interview data

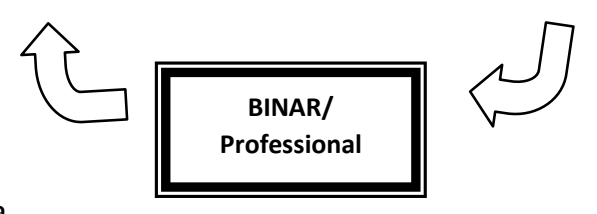

The non-poor

Figure 1 The cycle of BMB's programs

The Baitul maal model is included in this study as it represents an approach to the integration of Islamic charity and microfinance. It shows how a commercial institution's social function can support the development of the whole institution, without endangering institutional sustainability.

\section{Profile of the Clients}

The study collected data of the profile of the clients of three ICBM institutions using survey questionnaires. The survey questionnaire was taken by 4 groups of respondents: one for each of the case study institutions (3 groups, 154 participants) and one group of non-clients (82 participants). Overall, most respondents were older than 45 years had graduated from primary school, and were members of small family households headed by men. Notably, BQB's clients were significantly older than the non-client group. By contrast, the age difference between BMMI's and BMB's clients and the non-client group is not statistically significant.

In relation to clients' formal education levels, BMMI and BQB's clients had completed their formal schooling (Years 7.8 and 7.5 years respectively). This finding indicates that these particular clients have very limited education and did not complete Indonesia's compulsory nine-year education period. Clients were also found to have experienced fewer years of formal education compared to the non-client group. In contrast, $\mathrm{BMB}^{\prime}$ s clients remained in the formal education system for a longer period compared to the clients' of BMMI and BQB. On family size, the ICBM clients lived in small family units with two or three children. In particular, BQB and BMB clients lived in significantly larger sized family units compared to those of the non-client group. In contrast, BMMI's clients and non-clients live in similarly sized family units.

In relation to the gender of the head of client and non-client households, in all groups this role was taken predominantly by the male. Particularly, there are $27 \%$ of BQB's female clients and $17 \%$ of BMMI's female clients who play a role as the head of the family. The study also found that there were more female as head of the family in BQB than that of the non-client group. For clients who lived in Yogjakarta, around $8 \%$ of families have female as the household head. The study also found that there are significantly fewer female playing the head of the family role in the BMB client group than that of the non-client group. A summary of clients and non-clients' profiles are presented in the Table 1 
Table 1 Demographic profiles of the case ICBM clients and non- clients

\begin{tabular}{llllll}
\hline & \multicolumn{2}{l}{ Mean } & & & \\
\cline { 2 - 7 } Family characteristics & \multicolumn{2}{l}{ Jakarta } & & \multicolumn{2}{l}{ Yogyakarta } \\
\cline { 2 - 7 } & BMMI & $\begin{array}{l}\text { Non } \\
\text { Clients }\end{array}$ & BMB & $\begin{array}{l}\text { Non } \\
\text { Client }\end{array}$ \\
\hline Age of household head (years) & 46.77 & $49.11^{* *}$ & 45.6 & 47.36 & 49.28 \\
\hline $\begin{array}{l}\text { Formal education Year level achieved } \\
\text { (years) }\end{array}$ & 7.8 & 7.48 & 8.23 & 9.04 & 8.46 \\
\hline Family size & 4.3 & $4.75^{*}$ & 4.05 & $4.06^{* *}$ & 3.24 \\
\hline Percentage of male household head (\%) & 83 & $73^{* *}$ & 83 & $92^{* *}$ & 78 \\
\hline Total & 48 & 63 & 59 & 50 & 50 \\
\hline Source: survey
\end{tabular}

Source: survey questionnaires data, ${ }^{* *}$ significant at $95 \%$ confidence level, ${ }^{*}$ significant at $90 \%$ confidence level

To understand the poverty level, the study compared the annual per capita income and monthly per capita food expenditure of both clients and non-clients. The questionnaires asked respondents to provide information about their food expenditure over the previous one month. The researcher considered that participants would be able to readily recall one month's stock of information particularly if requested close to the survey period. Respondents provided an estimate of the cost of their food intake by using a standardized measure of a unit of consumption, calculated on food costs at the time of the survey of common food items in Indonesia: rice, meat/fish/tempe/tofu, vegetables, instant noodles, milk, sugar, coffee/tea, fruit, and cooking oil.

Overall, clients spent less of their income on food than the non-client group; but the difference may not be statistically significant. It was found that only BQB's clients spent statistically significantly less on food consumption compared to the non-client group.

Table 2 Clients and non-clients monthly food expenditure Mean in rupiah (\$)

\begin{tabular}{llllll}
\cline { 2 - 6 } & BMMI & BQB & $\begin{array}{l}\text { Non } \\
\text { Clients } \\
\text { Jakarta }\end{array}$ & BMB & $\begin{array}{l}\text { Non- } \\
\text { Clients } \\
\text { Yogjakarta }\end{array}$ \\
\hline $\begin{array}{l}\text { Monthly per- } \\
\begin{array}{l}\text { capita } \\
\text { expenditure }\end{array}\end{array}$ & $\begin{array}{l}260,998.02 \\
\$ 1.32)\end{array}$ & $\begin{array}{l}242,757.34^{* *} \\
(\$ 1.23)\end{array}$ & $\begin{array}{l}327,536.37 \\
(\$ 1.66)\end{array}$ & $\begin{array}{l}192,026.32 \\
(\$ 0.97)\end{array}$ & $\begin{array}{c}204,093.03 \\
(\$ 1.03)\end{array}$ \\
\hline
\end{tabular}

Source: survey questionnaire data, ${ }^{* *}$ Significance at $95 \%$ confidence level

The study also collected data on clients' and non-clients sources of household income averaged over a 12 month period up to the time of the study to allow for seasonal fluctuations. The survey data indicates that many of the case study ICBM clients were found to be running self-employed enterprises with some assistance from other family members. These enterprises were located mainly within the informal market sector and comprised street vendors and petty traders, selling convenient food, snacks, cigarettes, drinks, and daily food supplies, from small shops/stalls at the front of their houses, in market places, or other busy locations, or door-to-door. Using the study's observational data, most of these enterprises require minimum skills, have low barriers to entry and operate in a very competitive environment.

In addition, the survey data presented in Table 3 found that the annual per capita income of clients and non-clients was greater than the minimal World Bank standard of \$US2 per day. In Jakarta, the study found that the average of clients' per capita income levels is lower than that of the non-client 
group. By contrast, the average of clients' per capita income levels in Yogjakarta is higher than that of the non-client group.

Table 3 Clients' income levels

\begin{tabular}{llllll}
\hline Variable & BMMI & BQB & $\begin{array}{l}\text { Non-clients } \\
\text { Jakarta }\end{array}$ & BMB & $\begin{array}{l}\text { Non-Clients } \\
\text { Yogjakarta }\end{array}$ \\
\hline $\begin{array}{l}\text { Annual per capita } \\
\text { Income in Rupiah }\end{array}$ & $\begin{array}{l}7,667,395 \\
(\$ 1166)\end{array}$ & $\begin{array}{l}5,990,063 \\
(\$ 911)^{*}\end{array}$ & $\begin{array}{l}8,555,788.18 \\
(\$ 1301)\end{array}$ & $\begin{array}{l}(\$ 884.817,300 \\
(\$)\end{array}$ & $\begin{array}{l}5,468,979 \\
(\$ 831.7)\end{array}$ \\
\hline
\end{tabular}

Source: survey questionnaire data, ${ }^{*}$ significantly difference to the non-clients income at $90 \%$ confidence level

The survey data revealed that client and non-client incomes are generated from multiple sources. Along with running a single micro-enterprise, clients and non-clients may also engage in other productive activities such as undertaking paid labor in households and local industries. The survey data further show that for the majority of clients, the head of the family and their spouse both need to generate income in order to meet even the most minimal of household expenditure demands. The household income generated from the household head alone will not be sufficient to fulfill the daily expenditure demands of lower income level households. As such, other family members also need to find ways of generating income to support the family. Loans provided by the case ICBM institutions are frequently used as start-up capital to initiate homebased microenterprises as a second source of income.

The analysis of clients' and non-clients' responses to survey questions probing annual per capita income levels and monthly food expenditure threw light on four key findings. Firstly, BMMI's and BMB's clients' monthly food expenditure is not significantly different to that of the non-client group. Secondly, BQB's clients spend significantly less on food compared to non-clients. Thirdly, the annual per capita income of BMMI's and BMB's clients is not significantly different to that of the non-client group. Lastly, the annual per capita income of $\mathrm{BQB}^{\prime}$ s clients is significantly lower than that of the non-client group.

To sum up, the study was revealing in its findings that $B Q B$ appears to have selected clients who have both lower per capita income levels and monthly food expenditure levels than the non-client group; while BMMI and BMB seem to have selected clients who are at almost equal annual per capita income and monthly per capita food expenditure levels as non-clients. In other worlds, these findings indicate that BMMI and BMB fail to include the poorest of the poor in the program.

\section{Program fundings}

The breakdown of funding sources reported in Table 1 shows that BMMI and BQB are funded primarily by zakat funds. This finding suggests that zakat is the most popular type of charity collected by the case study institutions, with more limited funding collected from shadaqa and waqf sources. By contrast, BMB collected more funds from shadaqa and infaq than from zakat such that BMB's funding base is made up of $60 \%$ shadaqa/infaq funds with $40 \%$ derived from zakat sourced donations. BMB's shadaqa collection amounts to $350-400$ million rupiah a year $(\$ 53,232$ to $\$ 60,837)$.

The study's document analysis of the ICBM institutions' financial reports showed that the overall amount of ICBM funds collected increased in the period of study. In less than one year BMMI alone experienced a substantial increase in the amount of charitable funds collected by 16.88 billion rupiah, while over the same period, funds collected by BAZNAS increased by only 0.22 billion rupiah. Table 1 provides the 2011 and 2012 funding composition data of BMMI and BAZNAS.

As subsidiaries of commercial financial institutions, BMMI (a subsidiary of Bank Muamalat Indonesia) and BMB (a subsidiary of BMT Beringharjo) enjoy some advantages. Both institutions benefit from the continual flow of Islamic charity funds from the main microfinance institutions' clients and employees to BMMI and BMB. Similarly, BMB also receives regular funds from 
employees' salaries and clients' zakat donations that are deducted monthly from their incomes that on average ranges from five to ten million rupiah each month.

BMB also received a significant amount of shadaqa and infaq funding comes predominantly from private companies' Company Social Responsibility (CSR) funds. BMB has been able to develop and sustain good relationships with these private companies to generate substantial, if at times irregular, contributions from CSR funds. As a consequence, BMB can report that it has sufficient funds to resource all of its programs and still maintain a funding surplus.

Table 4 ICBM providers' funding sources

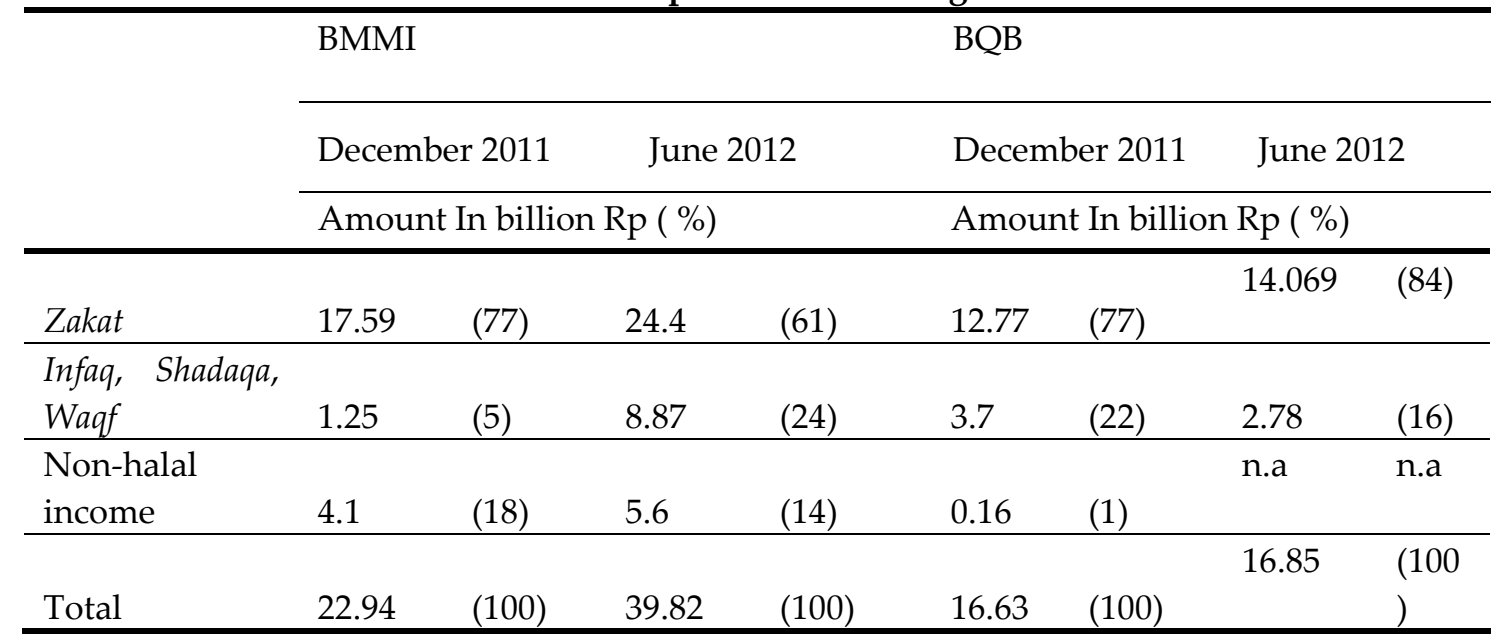

Source: Author's compilation from institutional reports

\section{Repayment rate}

In addition, this study also evaluates repayment rate of the financing given by ICBM institutions and its impact to institutional sustainability. The study found that repayment rate of financing given from zakat funding is very low. In the period of study less than half of the BMMI financing was being repaid. This study finding is interesting since it does not support the argument that loans disbursed in mosques will be sanctified such that the loans will be repaid on time.

Table 5 BMMI Repayment Rate

\begin{tabular}{llrll}
\hline & $\begin{array}{l}\text { Total financing } \\
\text { (in Rupiah) }\end{array}$ & $\begin{array}{l}\text { Total repayment } \\
\text { (in Rupiah) }\end{array}$ & $\begin{array}{l}\text { Repayment } \\
\%\end{array}$ & $\begin{array}{l}\text { Non-performing } \\
\text { financing } \\
\%\end{array}$ \\
\hline 2011 & $6,101,367,487.54$ & $3,421,889,029.01$ & 56.08 & 43.92 \\
\hline 2012 & $3,309,973,000.00$ & $689,968,425.00$ & 20.85 & 79.15 \\
\hline
\end{tabular}

Source: BMMI reports 2012

In addition, through document analysis of BQB reports presented in Table 6 the study was able to review the performance of $496 \mathrm{BQB}$ loans distributed in 2012. The data show that $58 \%$ of loans were repaid on time. The data also pointed to a relatively high percentage of non-performing loans, indicated at $22 \%$ of the total number of loans.

In response to the question related to low repayment rates, one of the fieldworker staff interviewed mentioned that there are not enough fieldworkers to monitor all the clients. In 2012, only approximately $15 \%$ of BQB's total clients were supervised and monitored by mentors. One fieldworker staff related, 'It is not non-performing, it do not perform well because we have never collected the repayment due to the lack of human resources'. The fieldworker's response supports the claim that the one of the major challenges facing ICBMs in achieving institutional sustainability is the lack of human resources. As noted previously, issues around the lack of human resources can often be put down to severe cuts to the institution's operating budget.

Despite human resource-related challenges, one $\mathrm{BQB}$ fieldworker indicated that low loan repayment rates may also be due to public perceptions of zakat as social organizations that simply 
disperse charitable funding directly to those in dire need, without an expectation that this funding be repaid. Many of the public are of the view that these recipients should take out loans in a more formal commercial context.

Table 6 BQB Loan Performance in 2012

\begin{tabular}{lll}
\hline & $\begin{array}{l}\text { Number } \\
\text { loans }\end{array}$ & of \\
\hline Well performing loan & 287 & 58 \\
\hline Not so well performing & 90 & 18 \\
\hline Non-performing & 109 & 22 \\
\hline No data & 10 & 2 \\
\hline Total & 496 & 1 \\
\hline
\end{tabular}

Source: BQB financial reports, 2012

\section{Community support and partnership}

A microfinance institution's community partnerships constitute a key resource in institutional efforts to achieve sustainability within the ICBM sector (Kaleem and Ahmed, 2009, Khan, 2011). This study found little evidence of supportive community partnerships in zakat-funded case study ICBMs.

Baitul Qirad Baznas (BQB) once enjoyed partnerships with PT WIN and KMU Mas Berlian to develop financial cooperatives. However, these partnerships were terminated due to different institutional mission orientations. Currently, many programs are managed solely by BQB. Within BMMI, program affiliations with several local microfinance institutions and local government owned zakat organizations turned out to be temporary due to significant cost inefficiencies. In contrast, BMB has continued to receive substantial support through its affiliations with private companies and community organizations such as Dompet Dhuafa, Permata Syariah, Pertamina, Amikom. Along with private company support, BMB are also affiliated with the religious organizations, Tangan Diatas, Jamaah Khusnul Khatimah, Nurani Insani, Dewi Khadijah and Sakinah. These organizations contribute Company Social Responsibility Funds to BMB's programs and make additional irregular donations.

According to BMB's management staff, the task of attracting adequate funding for client empowerment programs has proven to be more difficult. It seems that donors prefer to donate to programs that have direct observable impacts such as the immediate provision of clean water and natural disaster assistance, than to the funding of benevolent loans for the poor. To promote a better understanding of how the institution's empowerment programs contribute to a productive economy, and in the process possibly attract more funding, BMB conducts community microfinance education programs within mass religious training events.

The study also found instances of community support from community leaders and members in the form of other activities. Firstly, BMMI receives on-going support from the local religious leader who allows BMMI to use the local mosque as a central venue for BMMI's microfinance programs. The use of the mosque for group meetings and for client selection and monitoring activities has significantly reduced BMMI's operational costs. Second, from the interview responses the study identified various forms of community support within BMB's programs. As examples, the Association of Yogjakarta Dentists provides free dental checkups for BMB's clients in Yogjakarta and the Dewi Khatijah organization supports BMB's empowerment programs through its provision of food stalls and working capital for the jobless to enable them to initiate their own micro-businesses. Thirdly, as another form of support, successful BMB program graduates volunteer in BMB's mentoring program. The overall study findings indicate that the community has very limited volunteer involvement in ICBM programs and as such suggest there may be room to further develop volunteerism as a means to achieve institutional sustainability. 


\section{Operational cost}

Other challenging factor in serving the very poor is the high operational costs (Armendáriz and Morduch, 2005). This study found that BQB and BMMI also face this challenge. In the case of BMMI, its financial reports indicate that in 2011, total operational costs amounted to 2.6 billion rupiah, or almost $41 \%$ of its total financing. As mentor-supervised weekly client meetings incur significant operational costs, the use of a local mosque as the central venue for the institution's programs can reduce additional programrelated overhead costs. However, factors related to meeting frequency and the mosque's location, particularly if distant from the institution's main office, need to be considered in any cost-savings calculations.

In the case of BQB, total operational costs for 2011 were 181,082,321 rupiah, significantly higher than its total revenue of 77,368,406 rupiah. Possible reasons for this discrepancy between BQB's income and its operational costs may be due to the maximum allocation of zakat fund allowable to the management as governed by and stated in the Qur' an (QS 9:60). Zakat can only be distributed to eight categories of recipients, including zakat management. Allocations to zakat management of up to one eighth of the funds (i.e., $12.5 \%$ ) take first priority as a form of compensation for management's efforts in managing zakat. The balance of thefunds is used to cover all operational expenses: zakat management, including salary and wages, overhead costs, and promotional costs. This balance is likely to be insufficient to cover all operational costs and may mean that the human resources budget will be severely constrained.

High operational costs present a challenge to the achievement of institutional sustainability as ICBM institutions need to cover the costs of providing close client supervision and program monitoring activities. A limited operating budget may mean that staff numbers, staff performance incentives, and client support programs may need to be cut. Such cuts are likely to impact adversely in some way on clients' attempts to build successful microenterprises. The cuts may also impact on the outcomes of the institutions' loan programs in that cut backs in monitoring services may see lower rates of loan repayment.

In responding to questions related to employees' motivation to work in ICBM institutions, mentors interviewed revealed that their primary motivation to work with this type of financial institution was to serve their religion rather than to earn an income (BMB-3, 2011, BQB-2, 2011). The mentors claimed that they are not well compensated. From one staff member's viewpoint: 'The salary...is very sad, but I am happy to help others'. This statement may explain the high rate of staff turnover in many financial cooperatives in Indonesia. Sakai and Marijan (2008) assert that the problem of limited human resources is widely evident in Islamic financial cooperatives in Indonesia. They argue that the high staff turnover in Islamic financial cooperatives is due to lower salary rates compared to those offered in the commercial finance market sector.

\section{Factors affecting institutional sustainability}

Based on the discussion on several aspects above, the study findings identified several factors that may impact on ICBM institutional sustainability in either favorable or unfavorable ways. Overall, the case study ICBM institutions at the center of this study demonstrates key internal strengths in their capability to manage donated funds, create innovative program strategies, and make transparent their accountability mechanisms. Issues around the management of loan repayment rates, staffing, limited operating budgets, and meeting sharia compliance were identified as possible internal weaknesses that may jeopardize institutional sustainability. 
Table 7 Strengths and weaknesses impacting on institutional sustainability

Strengths

Weaknesses

\begin{tabular}{|c|c|c|}
\hline BMMI & $\begin{array}{l}\text { - Increasing amounts of } \\
\text { charitable funds collected } \\
\text { - The development of a profit } \\
\text { entity to reduce dependency } \\
\text { on charitable funds } \\
\text { - Support from local religious } \\
\text { leaders in utilizing local } \\
\text { mosques as central program } \\
\text { venues }\end{array}$ & $\begin{array}{ll}\text { - } & \text { Highly dependency on zakat } \\
\text { sources } \\
\text { - } \text { Limited volunteerism } \\
\text { - } \text { High operational costs } \\
\text { - } \text { Complexity to comply with } \\
\text { shariah } \\
\text { - } \text { Inherent complexities within } \\
\text { tamlik and sharia law } \\
\text { compliance practices } \\
\text { - Low loan repayment rate }\end{array}$ \\
\hline $\mathrm{BQB}$ & $\begin{array}{l}\text { - Increasing amount of } \\
\text { charitable funds collected } \\
\text { - } \begin{array}{l}\text { Innovative fundraising } \\
\text { schemes }\end{array}\end{array}$ & $\begin{array}{l}\text { - Highly dependency on zakat } \\
\text { sources } \\
\text { - Limited volunteerism } \\
\text { - Limited support from the } \\
\text { community } \\
\text { - Operational costs higher than } \\
\text { revenue } \\
\text { - Inherent complexities within } \\
\text { tamlik and sharia law } \\
\text { compliance practices } \\
\text { - Low loan repayment rate }\end{array}$ \\
\hline BMB & $\begin{array}{l}\text { - Increasing amount of } \\
\text { charitable funds collected } \\
\text { - } \text { The ability to develop } \\
\text { community partnerships } \\
\text { and to obtain CSR funds } \\
\text { - Program innovations } \\
\text { - Community involvement in } \\
\text { programs }\end{array}$ & $\begin{array}{l}\text { - Limited volunteerism } \\
\text { - Lack of a clear division of } \\
\text { funds }\end{array}$ \\
\hline
\end{tabular}

\section{Conclusion}

ICBM is a type of microfinance provision that draws on Islamic charity to provide financial and non-financial services for the country's poor who are identified as zakat recipients. The services offered by ICBM institutions include interest-free loan packages, mentoring programs, voluntary savings products, continuation programs and non-financial services, with an overall aim to empower and significantly enhance the wellbeing of zakat recipients.

The institutions' capability to provide continuous microfinance services to their clients is of central research interest in this study. To examine this issue, the study evaluated the institutional sustainability of three ICBMs provider in Indonesia using a case study approach This study has identified some of the case study institutions' internal key success factors and key structural challenges that may impact on the achievement of institutional sustainability. This study also evaluates the profile of the clients of ICBM institutions. The study's findings point out a lack of participation by the poorer in both BMMI's and BMB's microfinance programs. Some factors that can contribute to the lack participation are institutional clients selection policy, self exclusion due to society cultural value and selection mechanism. Those factors can be explored further in other studies. 


\section{Reference}

Abdullah, T. (1991). Zakat Collection and Distribution in Indonesia. In: ARIFF, M. (ed.) The Islamic Voluntary Sector in Southeast Asia. Singapore.

Ahmed, H. 2002. Financing Microenterprises: An Analytical Study of Islamic Microfinance Institution. Islamic Economic Studies, 9.

Ahmed, H. 2004. The Role of Zakat and awqaf in Poverty Alleviation, Jeddah, IRTI.

Ahmed, H. 2007. Waqf -Based Microfinance Realizing the Social Role of Islamic Finance. Integrating Awqaf in the Islamic Financial Sector. Singapore.

Bremer, J. (2013). Zakat and Economic Justice: Emerging International Models and their Relevance for Egypt. Third Annual Conference on Arab Philanthropy and Civic Engagement, Tunis, Tunisia

Firdaus, M., Beik, I. S., Irawan, T. \& Juanda, B. (2012). Economic Estimation and Determination of Zakat Potential in Indonesia. Jakarta: IRTI IDB.

Hassan, N. M., Nor, A. H. B. M. \& Rom, N. A. M. (2012). Embracing Microfinance: Proposed Collaboration Between Zakat Institutions and Microfinance Institutions. 3rd ICBER 2012 Proceeding.

IRTI. (2014). Islamic Social Finance Report. Jeddah Saudi Arabia: IRTI Islamic Development Bank and Thomson Reuter.

Kahf, M. D. (2006). Role of Zakat and Awqaf in Reducing Poverty: A proposed Institutional Setting within the Spirit of Syariah. Thoughts on Economics, 18.

Lewis, O. (1971). The Culture of Poverty. In: Pilisuk, M. \& Pilisuk, P. (eds.) Poor Americans: How The White Poor Live. United State of America: Transaction,Inc.

Nugroho, A. E. 2010. Market segmentation, Social Capital, and Welfare-Outreach in Microfinance: a Case Study in Indonesia. Doctor of Philosophy, Curtin University of Technology.

Qardhawi, Y. (2009). Figh Al Zakat, Jeddah, Saudi Arabia, Scientific Publishing Centre.

Sarif, S. \& Kamri, N. A. (2009). A theoretical Discussion of Zakat for Income Generation and Its Fiqh Issues. Jurnal Syriah, 17, 457-500.

Schicks, J. (2007). Developmental impact and coexistence of sustainable and charitable microfinance institutions: analysing BancoSol and Grameen Bank. The European Journal of Development Research, 19, 551-568.

Setiawati, L. \& Guritno,.(1997). Budaya Kemiskinan di Desa Tertinggal di Jawa Timur: Kasus Desa Tarokan, Kecamatan Banyuanyar, Kabupaten Probolinggo, Jakarta, Departemen Pendidikan dan Kebudayaan Direktorat Jenderal Kebudayaan

Simanowitz, A. \& Walter, A. .(2002). Ensuring Impact: Reaching the Poorest while Building Financially Self Sufficient Insitutions, and Showing Improvement in the Lives of the Poorest Women and Their Families. In: Daley-Harris, S. (ed.) Pathways out of Poverty: Innovations in Microfinance for the Poorest Families. Connecticut: Kumarian Press.

Singer, A. (2008). Charity in Islamic societies, Cambridge University Press.

Wan Ahmad, W. M. \& Mohamad, S. (2012). Classical Jurist' View on the Allocation of Zakat: Is zakat investment allowed. Middle East Journal of Scientific Research, 12, 195-203.

Yumna, A. \& Clarke, M. (2011). Integrating zakat and Islamic charities with microfinance initiative in the purpose of poverty alleviation in Indonesia. The 8th International Islamic Economic and Finance Conference. Doha, Qatar. 